SHS Web of Conferences 6, 02003 (2014)

DOI: $10.1051 /$ shsconf / 20140602003

(C) Owned by the authors, published by EDP Sciences, 2014

\title{
The Progressive Realization of Equal Rights of Chinese Farmers: History, Reality and Future
}

\section{Lv Yuntao}

China University of Petroleum, School of Economics and Management, 266580 Qingdao, China.

\begin{abstract}
Compared with urban residents, great inequality exists as to the rights of farm laborers. Chinese Government has made great efforts to achieve equal rights for farmers. Farmers' equal rights have got a lot of qualitative leap: the agricultural tax exemption, the rural and urban tax fairness; exempt from compulsory education fees, to achieve equality in education; establishing a new rural cooperative medical care, to achieve equal health insurance rights; establishing a sound social security system in rural areas, to achieve equal social security rights; amending the electoral law, to achieve equal voting rights. Due to historical reasons, there are still some problems and obstacles, such as a big gap in the urban-rural income and consumption, and uneven distribution of public resources in urban and rural areas. The government should reform rural household registration system in-depth, promote urban-rural integration to achieve the equalization of allocation of public resources, to ensure equal rights for farmers.
\end{abstract}

Keywords. farmers' equal rights; rural household registration system; urban-rural integration; the equalized distribution of public resources

\section{The Introduction}

The report of Eighteenth National Congress of the Communist Party of China stressed again that properly Solve agriculture, rural areas and farmers' problem is a top priority of the party's work. Citizens enjoying equal rights, is an important aspect of social justice, what is more, it is the government goal. Due to historical reasons, Chinese farmers and urban residents have significant inequalities in fundamental rights, especially the right to education, the right to health insurance, social security, the enjoyment of the right to vote, etc. After the reform and opening up, especially after entering the new century, the Chinese government has made a great effort to achieve equal rights for farmers and the equal rights of farmers have achieved a lot of qualitative leap, but there are still some problems to be solved. Therefore, to explore the history and reality of the Chinese farmers' equal rights gradually realizing, and Envisioning its future development, has important theoretical and practical significance.

\section{History form: Chinese Farmers' Rights inequality}

Compared with urban residents, the rights enjoyed by Chinese farmers in all aspects of political, economic, social and cultural relatively exists large gap and inequality, such as unfair taxation, education inequality, life and health inequalities, social security inequality, unequal voting rights, etc. 
the right inequality of Urban and rural residents is caused by history objective needs and institutional arrangements. Urban and rural social structure is the root which caused the unequal rights of urban and rural residents. Formation of urban-rural social structure is the result of many economic and social factors. Additionally, it's also the result of the strategy to protect priority to the development of heavy industry in order to achieve the dual household registration system as the core of a series of institutional arrangements.

Founding of New China, from 1949 to 1957, is a short but valuable account of freedom of migration period. Citizens are free to live and migration, citizens who move in and out only requires formalities, not made strictly limited. From 1952 to 1957, about 2,000 million farmers flow into the city.[1] A large number of peasants flowing into the cities made some new problems. In order to alleviate the pressure of the city, in 1953, 1954, 1955 and 1957 government on four occasions instructed to discourage farmers blindly into the city, trying to control the size of the urban population, limiting farmers into the city. In 1958, "People's Republic of Household Registration Ordinance" is passed, Restricting farmers into the household registration system begin to finalize in the form of legislation. Since then, enter into the period that strictly limited account migration, especially strictly limits farmers migrate to cities. In 1963 , the Ministry of Public Security of the census, according to whether eat the supply of grain as a national plan criteria for the classification into the account the nature of the agricultural and non-agricultural household accounts. Urban and rural household registration system division was officially formed.

Meanwhile, in order to solve the contradiction between the priority development of heavy industry and the backwardness of agriculture, to protect industrialization and market stability, since 1953, China has gradually implemented agricultural purchase and sale of cotton and other agricultural policies. Purchase and sale not only as a precondition to urban-rural split, its implementation effectively limits the mobility and migration of the rural population, Curing the urban and rural social structure.

In addition, the state has also developed a series of supporting the household registration system, in the interests of the urban bias point to the written and unwritten auxiliary systems, household factors to fully penetrate all areas of social life. Farmers become an identity no more than one career. In all aspects of the right Farmers and urban residents produce inequality.

Implemented a national urban residents more than ten security benefits system, in addition to protect employment, but also including residential, grain, food, fuel supply, education, health care, insurance, labor protection, marriage, conscription system. Implementation of the national rural people to help as the main relief and social security, indeed farmers themselves assume responsibility for the supply of public goods, which Led to an excessive burden on farmers, a serious shortage of rural public goods supply, a number of damage to the interests of farmers. In the Commune period, these public goods mainly by the commune or production brigade burden after the reform and opening up, changing the form of townships and village reserve. Farmers' actual burden is heavy but they enjoy these resources are very limited.

In addition, in the aspect of the right to vote, when determining the number of people's congress, the electoral law is according to the Principle that each representative represent in the country is a few times each representative represent in the city, this not entirely consistent with the constitution about who has the right to vote and to be elected, which deprived the right to vote and to be voted from part of the farmers, causing inequality between voting rights of urban and rural areas. In 1953, The first electoral law: the election of National People's Congress, the number of rural and urban proportion of the population represented by each delegate $8: 1 ; 1979$ the electoral law, the proportion without making modifications; 1995's "Election Law" changed it to 4:1, which lasts until 2010. From the previous National People's Congress we can see that, the farmer representatives population accounts for the proportion of the National People's Congress and peasants accounted for the proportion of the population is in imbalance.

\section{Breaking reality: Chinese government's efforts to make equal rights of farmers to achieve}


Faced with the problem of inequality of urban and rural residents' rights, the Chinese government has been actively seeking solutions, and Urban and rural residents equal rights is gradually implemented .Especially after enter into the 21 st century, the Chinese government launched a series of major reforms to agriculture, rural areas and farmers, these reforms greatly facilitate the realization of equal rights of farmers.

\subsection{Agricultural tax exemption, and strive to realize the urban and rural tax fairness}

After the founding of new China, according to the relevant provisions, the Chinese government collects agricultural tax in the rural areas. Began in 1983, the government decided to start the collection of agriculture and forestry specialty agricultural tax. In 1994, it changed to agricultural specialty agricultural tax. In pastoral areas, according to the authorization, livestock tax is imposed. So far, our country agriculture tax system actually includes the agricultural tax and taxes on special agricultural products and $\mathrm{Mu}$ Ye Shui three forms. Since 2000, the government began to actively explore the reform of rural taxes and fees, making efforts to achieve urban and rural to fair. In 2000, the government decided to take the lead in Anhui province for the pilot reform of rural taxes and fees. In 2002, the pilot expanded to 20 provinces. In 2003, the government issued "opinion about promoting the reform of rural taxes and fees pilot work “. In 2004 the government work report announced: "from this year, China begin to reduce the tax rate gradually, more than one percent a year on average, to cancel agricultural tax in five years." The government work report in 2005 said: in 2006, agricultural tax will be canceled in the Nationwide. This marked our country has implemented a 2600 - year old tax. Compared with 1999, before the reform of rural taxes and fees, cancellation of agricultural tax makes farmers reduce the burden of more than 100 billion yuan a year, reducing the burden of around 120 yuan per person and 800 million farmers benefit. The heavy taxes on farmers get completely solved, making urban and rural tax to the fair.

\subsection{Free compulsory education tuition, and strive to realize the equality of education}

Due to historical reasons, there exists a big difference on the urban and rural compulsory education funds investment. In the city, most are to be borne by the government, and in the rural villages, collective and individual farmers undertake most of education funds. Not only poor school conditions, farmers' children also have to afford the high tuition and other miscellaneous school fees. Compulsory education tuition become an important constitute part of the burden on farmers. In the 21 st century, the Chinese government embarked reform on this.

The reform began at the end of 2005. On December 23, 2005, the state council noticed about deepening safeguard mechanism of the reform of rural compulsory education funds, request that rural compulsory education must be fully included into the public finance, to establish the central and local projects, Proportional share of the mechanism for ensuring adequate funding for rural compulsory education. In 2008, the government work report "the implementation of free compulsory education in urban and rural throughout the country", on the basis of the pilot, since 2008, urban compulsory education tuition and fees will be fully exempted. From then on, the urban and rural students enjoy free compulsory education, urban and rural residents was preliminarily realized the equality of education right.

\subsection{To establish a new type of rural cooperative medical care, and strive to realize the equality of the right of health insurance}

Since 2001, our country began to explore the new rural cooperative medical care system. "The local people's governments at all levels should strengthen the cooperation of medical organization and leadership. According to the principle of voluntary measure, adjust measures to local conditions, by civilian, continue to improve with the development of cooperative medical care system. Cooperative medical financing is given priority to with individual investment, collective support, government 
support, appropriate financial openness and democratic management. Promotes the city for the unit to the poverty-stricken, helping farmers against the risk of a serious illness that personal and family is difficult to bear." In 2005, the government proposed to further increase the intensity of the central and local financial support, in 2006 the pilot city, area by $21 \%$ of the country's expanded to about $40 \%$, the central government to attend the allowances for rural cooperative medical system on the basis of the original 10 yuan per person per year to add 10 yuan, the agricultural population accounts for most of the central and western regions to municipal district and eastern part to participate in the pilot city of difficult into the scope of the fiscal subsidy. Local governments should increase subsidies. Don't improve the pay cost standard of farmers, increase the burden on farmers. In October 2007, the party's 17 th national congress of the "everyone will have access to basic medical and health services" as one of the important goals of building a moderately prosperous society in an all-round way.

After several years of efforts, the new rural cooperative medical care system has achieved full coverage. The participant in the new rural cooperative medical care over 810 million, the participation rate reached $91.5 \%$.

July 2007, issued a "guidance on carrying out the basic medical insurance system for urban residents," and proposed "by the pilot to explore and improve the basic medical insurance for urban residents policy system, form a reasonable funding mechanism, a sound management system and norms operating mechanism, and gradually establish a serious co-ordination based basic medical insurance system for urban residents." By 2009, 401 million people are in urban workers and urban residents basic medical insurance. The right of Urban and rural residents basic medical insurance realize to equality.

\subsection{Establish a sound social security system in rural areas, achieve equal social security right}

In the long-term urban-rural dual system, the social security system in rural is lagging behind seriously. With the reform and opening up and the economic development, the government began to establish social security system in rural areas gradually. After 2006 China began to construct new socialist countryside, the largest pension system and livelihood security system has entered a rapid development period.

2006 "CPC Central Committee decisions on a number of major issues concerning the socialist harmonious society," presented strategic objectives that to the 2020 "establish basic social security system covering urban and rural residents", clarified the social security "a significant system in protection of social fairness and justice".

In 2007 the State Council issued "Guidance on basic medical insurance for urban residents to carry out pilot "and "Notification on the establishment of the national rural minimum living security system." In December 2007, the first meeting of the NPC Standing Committee to consider the "PRC Social Insurance Law (draft)".

2008 "CPC Central Committee decisions on a number of major issues concerning rural reform and development" demanded to implement wide coverage, basic protection, multi-level, sustainable principles and accelerate the establishment of rural social security system.

In 2009 the State Council issued the "State Council guidance on carrying out new rural social pension insurance pilot", and proposed that "explore a new agricultural insurance system combined with the individual contributions, collective benefits, and government subsidies, implement a system combined social pooling and individual accounts, integrated with family pension, land security, social assistance and other matching guarantee systems, guarantee the basic life of the elder rural residents. Gradually expand the pilot implementation, realize the full coverage of rural conform-age population basically by 2020 “. In 2009, about 15,300 thousand people over the age of 60 began to receive a monthly payment of the national basic pension in rural areas. [3]

\subsection{Modify the electoral law, to achieve the equality of electoral rights}


Chinese farmers have great differences from urban residents in the possession of actual political rights and interest-expression mechanism, a prominent example is the different proportion of representatives. Party and the government have gradually valued this issue. In 2007, the party's congress report states: "expand people's democracy, ensuring people be the host", "recommended the same proportion representatives among urban and rural. "2008 Third Plenary Session "CPC Central Committee on rural reform and development's certain major issues" further clarified that: "recommended the same proportion representatives among urban and rural, expanding the proportion of farmers in the county deputies, in close contact with the peasants deputies. "On March 14, 2010, the Third Session of the Eleventh National People's Congress voted to adopt a decision on amending the electoral law, which marked China's socialist democratic politics has taken a historic step forward. The new revised "Electoral Law" clarified that "Under the principles that each one represent the same urban and rural population and that all regions, all nationalities, all aspects have an appropriate number of representatives, the National People's Congress Standing Committee in accordance with the population of all provinces, autonomous regions and municipalities allocate the quota of representatives." this change means the realization of the electoral and political rights to the principle of equality and a big step to promote the constitutional principle of equality fully realized.

\section{Dilemma: The main obstacles still exist in the achievement of equal rights}

\subsection{Larger income and consumption gap between urban and rural}

In recent years, the Chinese government attaches great importance to rural issues, issued a series policy, which to some extent, prevented the gap between urban and rural areas growing, but it has not been fundamentally reversed. In 1985, per capita disposable income of urban residents was 1.86 times than rural residents, in 1995, the rate rose to 2.71, and in 2007 reach to a high 3.33; in 2008, a slight decrease but still reached 3.31, in 2009 the rate was back to3.33:1 again . The absolute income gap between urban and rural residents is more obvious, from 11,020 yuan in 2008 up to 12,022 yuan. In addition to the income gap between urban and rural areas, rural income gap is equally clear. By the 1196 yuan standard, the rural poverty is still 35.97 million people at the end of 2009. The income levels largely determine the level of consumption. At present, the rural consumption level is low, rural residents which are nearly $2 / 3$ of the total population consume only $1 / 3$ of the whole productions, the Engel coefficient of rural households still up 43.7\%. [4] Thus, the large income gap between urban and rural and among the rural is neither conducive to the realization of overall, long-term goal of building a well-off, nor conducive to expand rural demand and achieve the short-term goals to adjust the economic growth structure.

\subsection{The public resource distribution is still uneven between urban and rural}

In recent years, the central focus on adjusting the distribution of national income, public finance system construction began made big headway. However, due to historical debts, the public services in rural areas still have many problems. Despite the exempt from the compulsory education tuition and the increasing investment in rural education, the education resources' distribution is still unequal. Urban areas is still significantly better than rural schools whether it is configured with a faculty, invested funds for education or teaching facilities, equality of educational opportunities. Compared with the urban social security system, social security system in rural areas is still relatively weak. In general, China's social security in rural areas is lagging behind, the protect surface is narrow, the protection level is low.

\section{Future prospects: Further realization of equal rights in rural}




\subsection{Reform of household registration system and make farmers the equal national treatment}

The household registration system is the carrier of urban and rural social structure. We must reform the household registration system to remove the obstacles for farmers equal rights. Reform of the household registration system is a complicated systematic project, it must be linked to the household registration system, the employment system, education system, financial system, social security system for a comprehensive reform. Breaking the limits between "agricultural population " and "non -agricultural population," so that citizens get a unified identity, removing the adhering to the domicile of socio-economic differences so that citizens get a equal national treatment. "Freedom of movement "must be re-written to the constitution as soon as possible and strictly protected as a fundamental right. Establishing a unified national household registration management system, and ultimately establish a freedom account migration system. The integrated household registration system will eliminate unreasonable restrictions and constraints on migrant workers. The city settled farmers should enjoy the same employment, medical care, child nursery, school and other social services as urban residents, which enable them to become true urban residents.

\subsection{Further promote the integration of urban and rural economic and social development, achieve the equalization of public resources}

We must set up a system to promote the integration of urban and rural economic and social development, promote public resource's balanced allocation between urban and rural areas, and promote the integration of urban and rural economic and social development. We must integrate urban and rural infrastructure and public services, comprehensively improve the level of financial security in rural areas, and gradually establish a unified public service system. To strengthen the protection of migrant worker's rights, and progressively realize the same treatment in migrant workers pay, children's education, health, and housing, as soon as possible. Equalization of public resources in the region means equitable delivery between urban and rural or different regions, citizens enjoy equitable public resources such as employment, education, health care, social security and so on. Entitled to fair and equal social treatment the equal rights of farmers is possible to realize. To expand the scope of public finance coverage in rural areas, develop the rural public utilities, so that the farmers can get education when they want, get income from work, get medical services when sickness, get security when aged, and get housing when they need. And we should achieve inter-regional equalization of public resources firstly to make all Chinese citizens enjoy equal public resources.

Human beings are born to be equal in dignity and rights. Engels pointed out: "Once the economic progress of the society set requirement that get rid of the shackles of feudalism and feudal inequalities by eliminating the requirement to establish equal rights on the agenda, this requirement will surely rapidly expanding its range. As long as the industrial and commerce workers get these requirements, we must demand the same for the majority of farmers." The achievement of farmer's rights equality is the inevitable requirement for building a harmonious socialist society, [6] The Chinese people will live a happier life with more dignity, more justice and more harmonious with the equality of farmers' rights.

\section{Acknowledgment}

This paper is the initial results of the project supported by the Fundamental Research Funds for the Central Universities (GN:12CX04004B)

\section{References}

1. Tiejun Wen. How Do We Lose the Freedom of Migration, China Reform, 2002 (4):22-23. 
2. Zuohan Zhou, Yinghong Zhang. Fundamental to Solve the Problem of agriculture, rural development and farmers: to Break the Dualistic Social Structure [J]. Contemporary World \& Socialism, 2004 (3):70-74.

3. Dejiang Zhang.Strengthen the Construction of Rural Social Security System, protect the basic livelihood of farmers more effectively [J]. Administration Reform, 2010(7):4-9.

4. Zhixiong Du. Income is Means, Welfare is Fundamental [N]. Chinese Social Sciences Weekly, 2010-5-13.

5. Selections of K. Marx and F. Engels. Vol. 3, People's Publishing House, 1995.447. 